\title{
A NEW LEASE ON LIFE: SECTION 23 HOUSING AND THE POOR*
}

\section{LaWrence M. Frredman $\dagger$ and James E. KrIer $\dagger \dagger$}

American efforts in public housing began in earnest during the 1930 's $;^{1}$ in the early years there were high hopes for the program's success. Since the end of the Second World War, however, the program has been unpopular with Congress, and has suffered from bad publicity, a bad public image and a constant lack of funds and imagination. Governmental disillusionment with public housing probably mirrors the disillusionment of the politically active public. In the big cities, public housing is commonly equated with highly segregated high-rise, high-crime projects, ugly in reputation and design. ${ }^{2}$ The political right always has despised public housing on the grounds that it is socialistic; ${ }^{3}$ the left generally has come to condemn the program on the grounds that it is dreary, despotic, discriminatory and dysfunctional. ${ }^{4}$ Public housing had become, by the early 1960's, one of the least popular federal welfare programs, devoid of all capacity for major growth and subject to withering attack.

To some extent, public housing has been more a scapegoat than a villain. It has been judged by its very worst examples; good projects are smeared by the same brush that tars the bad. Public housing is not the cause of many of the evils that projects admittedly embody. Public housing did not create the urban ghetto; the housing program, like the neighborhood school system, merely reflects the

* Research for this article was supported by funds granted to the Institute for Research on Poverty of the University of Wisconsin pursuant to the provisions of the Economic Opportunity Act of 1964.

$\dagger$ Professor of Law, University of Wisconsin. A.B. 1948, J.D. 1951, LL.M. 1953, University of Chicago. Member, Illinois Bar.

it Associate, Arnold \& Porter, Washington, D.C. B.S. 1961, J.D. 1966, University of Wisconsin. Member, Wisconsin Bar.

I The major piece of federal legislation was the Housing Act of 1937 (WagnerSteagall Act), 50 Stat. 888 (1937), as amended, 42 U.S.C. $\$ \$ 1401-36$ (1965), as amended, 42 U.S.C. $\$ 1402-36$ (Supp. 1967). On the legislative history of the Act, see T. McDonnell, The Wagner Housing Act: A Case Study of the Legislative Process (1957); on the forerunners of this legislation, see R. FISHER, TwENTY YEARS of Public Housing 73-91 (1959) ; Riesenfeld \& Eastlund, Public Aid to Honsing and Land Development, 34 Mrivis. L. REv. 610 (1950).

2 See Bauer, The Dreary Deadlock of Public Housing, 106 ARchitectural F., May 1957, at 139-42; Friedman, Public Housing and the Poor: an Overview, 54 CALIF. L. REv. 642, 643-46 (1966). On federal slum housing programs in general, see L. Friedman, Governarent and Slum Housing: A Century of Frustration (1968).

3 See, e.g., M. Friedman, Caprtalism and Freedom 178-79 (1962).

4 See, e.g., M. Harrington, The Other Aarerica 148-57 (1963). 
general pattern of segregation in the community. ${ }^{5}$ It would be selfdefeating to abandon public aid to housing because of de facto segregation in high-rise projects, just as it would be foolish to eliminate rather than improve public schools. Nevertheless, in recent years there has been a growing sense that traditional public housing is not the way to break the back of the slums.

Pressures for economic and social reform associated with the war on poverty and the revolt of the minority poor have been the outgrowth of this realization. New plans, programs and ideas have been flowing to and from Washington. The government and private foundations have been exploring ways to make housing available to the poor, while avoiding the standard public housing "project." Rehabilitation of existing dwelling units, small and scattered units of public housing, "turnkey" houses (built by private builders, then sold to housing authorities) ${ }^{6}$ have been tried. Finally, in 1965 , as part of the same major piece of housing legislation which included the rent supplement plan, ${ }^{7}$ Congress adopted the so-called leasing or leased housing program.

The basic plan of section 23 of the Housing and Urban Development Act of $1965,^{8}$ which embodies the leasing program, is quite simple. Local housing authorities are authorized and encouraged to take "full advantage of vacancies or potential vacancies in the private housing market . . . for the purpose of providing a supplementary form of low-rent housing which will aid in assuring a decent place to live for every citizen." 9 The public housing agency "shall conduct a continuing survey and listing of the available dwelling units within the community . . . which provide decent, safe, and sanitary dwelling accommodations and related facilities and are, or may be made, suitable for use as low-rent housing in private accommodations ... . "10 The agency, within the limits of the number of authorized units specified in its annual contributions contract ${ }^{11}$ with

5 On the tragi-comedy of site selection in Chicago, graphically illustrating the problems of trying to locate public housing projects anywhere but in the hard-core slum, see M. Meyerson \& E. Banfierd, Politics, Planning, and the Public InTEREST (1955).

6 See HUD, Buying From Developers, A New Approach to Public Housing, Oct. 1966; Wall St. Journal, June 6, 1966, at 1, col. 1. 1965).

7 See note 23 infra.

8 Housing and Urban Development Act of 1965, § 23, 42 U.S.C. § 1421b (Supp. I,

${ }^{9}$ Id. $\$ 23$ (a) (1), 42 U.S.C. §1421b(a) (1) (Supp. I, 1965).

10 Id. $\$ 23(\mathrm{~b}), 42$ U.S.C. $\$ 1421 \mathrm{~b}$ (b) (Supp. I, 1965).

11 The annual contributions contract outlines the basic relationship between the federal government and the local authority operating a public housing project. One of its chief clauses specifies the amount of the yearly contribution which the government undertakes to make to the authority to enable it to meet principal and interest on its bonds. See R. Fisher, Twenty Years of Public Housing 103-05 (1959). 
the federal government, may then notify and "invite" owners of suitable dwelling units to enter into contracts with the agency. Normally, the agency will rent no more than ten per cent of the units "in any single structure," but the agency may waive this requirement "because of the limited number of units in the structure or for any other reason." 12 The agency and the owner will be the parties to these contracts in most cases. ${ }^{13}$ "The selection of tenants" will be "the function of the owner," subject to the provisions of the annual contributions contract between the public agency and the federal government. ${ }^{14}$ Rent terms will be negotiated between the owner and the local authority, and rent will be paid directly to the owner by the authority. ${ }^{15}$ The low-income family usually will pay rent directly to the authority. ${ }^{16}$ The owner may "make representations to the agency for termination of a tenancy," but only the agency will have the right to evict." The lease may run no less than twelve months nor more than five years "and shall be renewable" by the parties at the expiration of the term. . $^{18}$

In short, the new law grants to local housing authorities the power to lease private homes or apartments for the use of low-income tenants ${ }^{19}$

12 Housing and Urban Development Act of 1965, §23(c), 42 U.S.C. $\$ 1421 b$ (c) (Supp. II, 1967) ; PHA Circular, Oct. 6, 1965, $\mathbb{1} 15$ [hereinafter cited as Circular]. See text accompanying notes 48-52 infra.

13 See Housing and Urban Development Act of 1965, §23(d), 42 U.S.C. §1421b (d) (Supp. I, 1965). It is possible under the program to have a direct lease between the assisted tenant and the private owner, with rent payments arranged through a collateral agreement between the local authority and the owner. Most cities which have come into the program so far have not made use of this option. It is, however, employed by the Boston Housing Authority. Telephone Interview with Frank Powers, Leasing Officer, Boston Housing Authority, June 2, 1967.

14 Housing and Urban Development Act of 1965, §23(d) (1), 42 U.S.C. §1421b

(d) (1) (Supp. I, 1965).

15 Id. $\$ 23$ (d) (2), 42 U.S.C. $\$ 1421 b$ (d) (2) (Supp. I, 1965).

16 This is the general practice and, indeed, is stressed by housing authorities as an advantage to property owners, since they do not have to worry about rent collections. See, e.g., Housing Authority of the City of Oakland, Section 23 Leased Housing and the Property Owner 4 (undated):

Question: Who collects the rent from the tenant?

Answer: The Housing Authority is responsible for tenant rent collections.

Question: If the tenant becomes delinquent in his rent, is the owner penalized?

Answer: No.

But see note 13 supra.

17 Housing and Urban Development Act of 1965, §23(d) (3), 42 U.S.C. § 1421b

(d) (3) (Supp. I, 1965).

18 Id. $\$ 23$ (d), 42 U.S.C. §1421b(d), (1966), as annended, Pub. L. 89-754, Title X, $\$ 1002,80$ Stat. 1284 (1966). Originally the initial term of leases was to be 12 to 36 months, and renewable. This was interpreted to allow a 3-year maximum initial lease and a 7-year maximum renewal term, or a total term of 10 years. Interview with Harry E. Zollinger, Department of Housing and Urban Development, Region VI Housing Assistance Office, in San Francisco, Nov. 16, 1966 [hereinafter cited as Zollinger Interview]; Circular IIT 1(a), 14, 19(a). The amendment referred to above is interpreted to allow an initial maximum term of $\mathbf{5}$ years and renewal up to 10 years, for a total of 15 years. Zollinger Interview; HAA Supplement to Circular, Dec. 5, 1966, amending If 1 (a), 14.

18 The "low-income tenant" is the same low-income person generally assisted by the public housing program. Circular $\mathbb{8} 8(\mathrm{a})$. 
and, hence, to abandon the concept of the "housing project" and to scatter subsidized tenants about the city. One housing administrator viewed the program, therefore, as "so radically different from conventional public housing" that it could hardly "be called by that name." 20 Leased housing conceivably might be used to crack the wall of race and income segregation; public-housing poor might live as neighbors with the middle class in middle-income apartment buildings or in houses located in middle-income areas. Federal cash contributions would help the subsidized tenant to meet his rent by making up the difference between what he could afford to pay and the fairmarket rent. The local housing authority would pay the differential to the owner of the dwelling. All parties would gain-the owner through a federal guarantee of the rent roll, the tenant from his subsidy, society and the housing authority through expansion of housing programs and increased integration.

The purpose of this article is to attempt a preliminary assessment of section 23 housing, and to explore whether it can succeed in attaining these objectives. Because the program is so new, the assessment must be largely speculative. In most cities, the program has not been in operation long enough for any final judgment. Moreover, like so many other social welfare programs, a realistic assessment of the section 23 program requires careful empirical study in the field. Fortunately, passage of the law was preceded by demonstration studies in a number of cities. ${ }^{21}$ Additional data is also available in the form of seminar papers on the operation of the program in three west coast cities, and through examination of local housing authority documents, personal interviews with west coast regional leasing officials and telephone interviews with leasing officials in selected cities across the country, including New York, Chicago and Boston.

\section{The Legislative Background}

Passage of the leasing provisions may have been revolutionary, but if so, the revolution has been a silent one. A not entirely unkind fate has sentenced the leasing program to obscurity. The program is often confused with the rent supplement (or rent subsidy) program, ${ }^{22}$

20 Address by Marie C. McGuire, Commissioner, Public Housing Administration, Houston Apartment Association, Houston, Texas, Jan. 18, 1966.

21 See, e.g., Aronov \& Smith, Large Families, Low Incomes, Leasing, $22 \mathrm{~J}$. Housing 482 (1965) (Washington, D.C. Study).

22 The confusion started with a running dispute over which program deserved the name "rent certificates." Compare Hearings on H.R. 5840 and Related Bills Before the Subcomm. on Housing of the House Contm. on Banking and Currency, 89th Cong., 1st Sess., pt. I, 279 (1965) [hereinafter cited as 1965 . House Hearings] with id. at 449, 456. See also Hearings on S. 1354 and Other Pending Bills Before a Subcomm. of the Senate Comm. on Banking and Currency, 89th Cong., 1st Sess. 
which was enacted as part of the same legislation. ${ }^{23}$ The subsidy plan was so controversial that it attracted disproportionate newspaper coverage and attention at the House and Senate hearings. Yet, the two programs are quite similar, in that both appear to offer the poor a chance to get subsidized housing outside public housing "projects"hopefully in middle-income areas. ${ }^{24}$ Actually, the rent supplement plan was originally proposed by the Administration as an aid for families just above the public-housing income bracket, ${ }^{25}$ the "rich poor" as they were called by one member of Congress. ${ }^{26}$ It was this aspect of the rent supplement plan which provoked much of the initial furor and drew unwanted attention to the program in Congress. ${ }^{27}$ Even after the program had been changed to benefit only those who would be eligible for traditional public housing, the controversy did not abate. $^{28}$ Public attention is not necessarily helpful in enacting welfare laws. The poor historically have lacked political power in the United States; the white middle-class, normally ignorant and unaware of welfare legislation, is peculiarly likely to object to such legislation, once attention is aroused. In this instance, publicity and debate nearly killed the rent supplement.

The leasing plan, on the other hand, remained quite obscure. Moreover, in contrast to the rent supplement program, which was

337 (1965) [hereinafter cited as 1965 Senate Hearings]. The leasing program seems to have won this particular battle. See, e.g., W. MILLER, THE FIFTEENTH WARD AND THE GREAT SocIETY 219 (1966). One newspaper article illustrates the confusion over labels. Obviously describing the leasing program, it refers to "the rent subsidy section of the 1965 Housing Act," the common name for the rent supplement program. N.Y. Times, Jan. 31, 1966, at 1, col. 6 .

23 Housing and Urban Development Act of 1965, § 101, 12 U.S.C. § 1701s (Supp. I, 1965). For a study of the rent supplement program, see Krier, The Rent Supplement Progran of 1965: Ont of the Ghetto, Into the . . ?, 19 STAN. L. REv. 555 (1967).

24 The similarities of the programs were pointed out during the hearings. See, e.g., 1965 House Hearings, pt. II, at 821. For statements contrasting the programs, to the disadvantage of the rent supplement, see id., pt. I, at 448-49; NAHRO Testifies Before Four Congressional Committees, March 30-April 5, 22 J. of Housing 185, 195 (1965).

25 See Krier, supra note 23 , at 556 and accompanying footnotes. The Administration also wished to rid itself of the below-market-interest-rate program provided for in $\$ 221$ (d) (3) of the National Housing Act, 12 U.S.C. $\$ 1715 l$ (1964), and use the rent supplement as the basic instrument for aiding lower-middle-income families. President Johnson advocated the rent supplement as a "crucial new instrument in our effort to improve the American city," and stated that "if it works as well as we expect, it should be possible to phase out most of our existing programs of low-interest loans." President Lyndon B. Johnson, The Problems and Future of the Central City AND Irs Suburbs, H.R. Doc. No. 99, 89th Cong., 1st Sess. (1965), reprinted in 1965 Honse Hearings, pt. I. at 72. at 230

26 Congressman William A. Barrett (Dem. Pa.), in 1965 House Hearings, pt. I,

27 See Staff of House Comm. on Banking and Currency, 89th Cong., 1st Sess., CoMpilation of Housing and URBAN DeVELOPMENT ACT of 1965, at 284-88 (Comm. Print. 1965) ; Krier, supra note 23, at 556 and accompanying footnotes.

${ }_{28}$ See Krier, sipra note 23 , at $556 \mathrm{n} .15$, describing the difficulties encountered by the program in achieving funding. The difficulties continued. In May, 1967, the House of Representatives refused to appropriate funds for rent supplements. N.Y. Times, May 18, 1967, at 1, col. 1. Funds were finally appropriated in November 1967. Act of Nov. 3, 1967, Pub. L. No. 90-121, 81 Stat. 356. 
handed over to the FHA, ${ }^{29}$ the leasing plan had the backing of the public housing bureaucracy, since it gave them control of administration. ${ }^{30}$ Finally, leased housing was not an Administration bill in the same sense as the rent supplement. The Administration submitted a long and detailed statutory plan to provide rent supplements; its leasing proposal was a short, rather bland and permissive section. ${ }^{31}$ Congress finally adopted the longer, and more specific Widnall plan. ${ }^{32}$ In his address on the Problems and Future of the Central City and Its Suburbs, President Johnson devoted a long statement to the rent supplement; leasing warranted only two sentences. ${ }^{33}$ The President fought bitterly for the rent supplement plan and ultimately succeeded in saving a piece of it; ${ }^{34}$ the leasing program was enacted without headline politics, fanfare or controversy. It continues to raise few national political problems and is alive, healthy and increasing in scope.

\section{Leased Housing: Objectives and Technigues}

\section{A. Economic and Racial Integration}

Only persons who cannot "afford to pay enough to cause private enterprise in their locality" to build adequate housing are eligible for

29 The National Association of Housing and Redevelopment Officials (NAHRO) opposed rent supplements. See, e.g., 1965 House Hearings, pt. 1, at 425-59; 1965 Senate Hearings at 301-38. In the view of Senator Paul H. Douglas, NAHRO's opposition was based largely on the threat of the rent supplement program to the authority and autonomy of local public housing officials. 1965 Senate Hearings 439,525 .

30 For the position of NAHRO in support of leasing, see 1965 Honse Hearings, pt. I, at $456 ; 22$ J. HousING 185, 195 (1965). NAHRO regarded local administration as an essential ingredient of the leasing program. Id.

31 H.R. 5840, 89th Cong., 1st Sess. $\$ 402$ (1965). See 1965 House Hearings, pt. I, at $40-41$.

32 H.R. 6501, 89th Cong., 1st Sess. $\$ 101$ (a) (1965). This portion of the Widnall Bill was enacted, without substantial change, in the Housing and Urban Development Act of 1965, § 23, 42 U.S.C. \$1421b (Supp. I, 1965), even though NAHRO objected that its provisions were too detailed. NAHRO felt that specifics should be left to administrative experimentation and determination. See. e.g., 1965 House Hearings, pt. I, at 458 .

Actually, the Administration proposal also was enacted into law. Housing and Urban Development Act of 1965, § 502, 42 U.S.C. \$1410(c) (Supp. I, 1965). The Administration proposal now embodied in this section establishes the so-called flexible formula and also serves as the legal basis for another program which differs from conventional public housing, but which diverges from strict section 23 housing "in that it will conform to all the traditional public housing requirements." Housing, Urban Development Act passed by Congress, emphasis put on low-income housing, 22 J. Housing 344, 347-48 (1965). Under this section, for example, public housing authorities might enter into long-term leases of private dwellings. During the hearings, the two proposals were regarded as being only technically different. See 1965 House Hearings, pt. I, at 364 .

The "flexible formula" is discussed in the text accompanying notes 92-99 infra.

33 President Lyndon B. Johnson, The Problems and Future of the Central CITY AND ITS SubuRBS, supra note 25 , at $72-73$.

34 Controversy over the rent supplement program by no means ended with passage of the bill. See note 28 supra. 
conventional public housing under both federal ${ }^{35}$ and state ${ }^{36}$ law. Moreover, tenants generally must vacate public housing once their incomes exceed a stipulated ceiling. ${ }^{37}$ Federal law specifically provides that the maximum income of those who qualify for public housing must be at least twenty per cent below the income necessary to obtain private housing on the market, except in the case of a displaced or elderly family. ${ }^{38}$ This twenty per cent provision reflects Congressional horror at the possibility that the government might compete with private builders and that the non-poor might insinuate themselves into subsidized housing. ${ }^{39}$ Since much post-war public housing has been built in big-city slums, the result of these policies is a rigid form of income segregation. The largest projects, such as Chicago's Taylor homes, with 4,414 families drawn from the ranks of the very poor, ${ }^{40}$ constitute ghetto cities in themselves.

Racial segregation is also a characteristic of big-city public housing. Although segregation was once at least tolerated by federal authorities, ${ }^{41}$ today integration is the ostensible norm for all public housing. ${ }^{42}$ Projects in the South, however, have remained completely segregated, ${ }^{43}$ and in the North the location of projects in Negro slums virtually ensures that the tenant population, with few exceptions, will

3542 U.S.C. $\$ 1402(2)$ (Supp. I, 1965). See also PHA Management Manual $\S 3.2 \mathrm{~b}$.

36 See, e.g., PA. Stat. Anv. tit. 35, $\$ 1553$ (1964) : "An Authority may rent or lease dwelling accommodations only to persons of low income."

3742 U.S.C. $\$ 1410(\mathrm{~g})(3)$ (1964). Despite objections to the rule, see, e.g., C. AbraMrs, THE CITY IS THE FrontIER 36-37, 265-66 (1965), it remains in force with only a narrow and rarely used escape clause, which provides that the ceiling does not have to be applied where "due to special circumstances, the family is unable to find decent, safe and sanitary housing within its financial reach although making every reasonable effort to do so ..." Housing Act of 1961, $\$ 205(\mathrm{~g})(3)$, 42 U.S.C. $\$ 1410(\mathrm{~g})(3)(1964)$.

3842 U.S.C. $\$ 1415$ (7) (b) (1964).

39 In practice, income ceilings in conventional public housing are even lower than the twenty per cent provision would require. Zollinger Interview.

40 PHA Low-Rent Project Directory-Chicago 99 (Dec. 31, 1965). A series of articles in the Chicago Daily Newes described the Taylor homes as the "world's biggest and most jam-packed housing development," a "civic monument to misery, bungling and a hellish way of life," a "death trap," and a "concentration camp." Chicago Daily News, April 10, 1965, at 1, col. 1.

41 In a few instances, "a segregated pattern for . . f federally managed projects" was actively fostered, e.g., in San Diego during the war, in projects managed by the Federal Public Housing Authority. D. MCENTIRE, RESIDENCE AND RACE 320 (1960). See also R. Weaver, Integration in Public and Private Honsing, 34 ANNALs 86 (1956).

42 Executive Order No. 11063, Nov. 20, 1962, 27 Fed. Reg. 11527 (1962), the famous "stroke of the pen," directed all departments and agencies of the Executive Branch to "take all action necessary and appropriate" to prevent racial discrimination in the renting of residential dwellings financed by federal money. PHA then issued an equal opportunity regulation, 24 C.F.R. $\$ 1500.6$ (1967). Title VI of the Civil Rights Act of 1964, $\$ 601,42$ U.S.C. $\$ 2000 \mathrm{~d}$ (1964), now covers public housing; see PHA Management Manual \$ 3.7.

43 The Miami Housing Authority, for example, had 14 housing projects under management as of December 31, 1965. Eight were all-white; five were all-Negro. PHA Low-Income Project Directory-Miami 50-51 (Dec. 31, 1965). 
be Negro. As of the end of 1965, no less than twelve projects in Washington, D. C., twelve in Baltimore and thirteen in Chicago were entirely non-white, and many others had only a token sprinkling of whites. ${ }^{44}$

The section 23 leasing program has raised hopes of ending de facto and de jure income and race segregation by making possible "an economic and social mix among subsidized and unsubsidized tenants." 45 Provisions of the leasing program are specifically designed to avoid the income segregation inherent in conventional public housing. The twenty per cent provision is expressly inapplicable to leased housing. ${ }^{4 \mathrm{~b}}$ Over-income tenants need not move, but may remain where they are, paying more rent and receiving less subsidy. If they earn more than the maximum for continued occupancy, they simply leave the program without necessarily having to leave their homes. ${ }^{47}$ Of course, at this point the landlord once more has the power to evict. In a slum or near-slum neighborhood, however, the over-income tenant who has "graduated" from the leasing program will usually be the most desirable tenant available.

Economic integration also can be promoted in the leasing program in two additional ways: poor and middle-class tenants can be mixed in one apartment building, or the poor can be housed in single dwellings in middle-class neighborhoods. The local leasing programs use both methods. Local authorities, as a general rule, are instructed to lease no more than ten per cent of the units in an apartment building, ${ }^{48}$ in order to promote economic and racial integration..$^{49}$ The ten per cent limitation, however, is only a guideline; the local authority, in its discretion, may permit subsidized occupancy greater than ten per cent and

$44 I d$. at $21,22,98-99$.

45 Address by Marie C. McGuire, Commissioner, Public Housing Administration, League of Women Voters of Louisville General Meeting, Louisville, Kentucky, Jan. 19, 1966 [hereinafter cited as McGuire Address].

46 Housing and Urban Development Act of 1965, §23(f), 42 U.S.C. $\$ 1421 b(f)$ (Supp. I, 1965); see Circular IfT 3(b), 8(a).

47 Circular $\pi 8(\mathfrak{f})$, provides: "If the owner is willing, the lease may contain an option giving the tenant the right to take over the lease in the event an increase in income causes him to become ineligible."

The leasing program, in a few cities, has been used to "bail out" a real estate project which has become financially shaky. The general expectation is that section 23 tenants will be desirable tenants and that landlords will want to keep them as long as possible. Occasionally this expectation may not be correct. This has been the experience where a middle-income project is built in a former slum area, and tenants shy away because the surrounding area has not yet been "purified" sufficiently for the tastes of the middle-class. Section 23 tenants provide financial salvation, which is expected to meet this temporary need. In at least one instance, the landlord has insisted on a one-year lease with the Authority, although ordinarily landlords have been eager to sign up for three-year, five-year or even longer terms, if possible.

48 See note 50 infra.

49 Both by assuring a mix initially and by avoiding such domination of an apartment building by the poor that middle-income families would move out. See N.Y. Times, Jan. 31, 1966, at 1 , col. 2 , and 17, col. 3 . 
probably up to one hundred per cent..5 This discretion is unreviewable, except for whatever pressures and inducements regional and national officials of HUD choose to exert. The ten per cent limitation appears to be little more than a warning to administrators not to create "projects" from used housing. In any event, it has no practical meaning in cities where most of the housing is in single-family homes or buildings of two or three units. The authors have spoken to leasing officials in a number of cities, none of whom feel that the limitation affects their behavior in any important regard. The ten per cent figure, according to one regional official, is "just a guideline, to avoid concentration. If you took a whole building, it would be identified as public housing, and have the stigma of public housing." 51 Yet, authorities would probably be willing to take a whole building, if the need arose. ${ }^{52}$

The leasing program also might advance economic integration through its power to place tenants in apartments and houses scattered throughout the city. The Administration hoped that the leasing program would "eliminate economic ghettos and the identification of low-rent dwellings as housing for the poor." 53 In many cities, housing authorities have been leasing single-family dwellings, either because this is the dominant form of housing in the community, or as a matter of policy. A PHA circular requires that leased dwellings be located in primarily residential neighborhoods which are "free of any characteristics seriously detrimental to family life," such as a predominance of substandard dwellings. ${ }^{54}$ Within these broad limits, the local authority is free to select sites as it wishes, ${ }^{55}$ but it can obtain dwellings only by negotiation; the power of eminent domain is not available. ${ }^{58}$ The local authority

50 The statute provides that the local authority shall lease no more than 10 per cent of the units in a structure, "except to the extent that the agency, because of the limited number of units in the structure or for any other reason, determines that such limit should not be applied." Housing and Urban Development Act of 1965, $\$ 23$ (a) (c), 42 U.S.C. \$1421b(c). See also Circular $\llbracket 15$ (local authority determination to lease more than 10 per cent of the dwellings in a structure does not require federal approval).

51 Telephone Interview with Harold Rosenfeld, Chief, Leasing Division, Region II (Philadelphia), June 1, 1966.

52 In Holyoke, Massachusetts, the leasing program has acquired all the units on four floors of a six-floor hotel for the use of the elderly; the New York regional office regards the limitation as a "dead letter." Telephone Interview with Irwin Halpern, Chief, Leasing Division, Region I (New York City), June 2, 1967. In Chicago, the Authority tries not to take more than one-third of the units in a building. In very large buildings, they try not to take more than six or eight units. But they make exceptions for elevator buildings to be occupied by elderly people. Telephone Interview with Gene Chmura, Program Coordinator, Leasing Program, Chicago Housing Authority, June 2, 1967.

53 Address by Marie C. McGuire, Commissioner, Public Housing Administration, Annual Convention of National Municipal League, St. Louis, Missouri, Nov. 15, 1965. 54 Circular $\ 11$ (a) (5).

55 For other limitations, see statement by Robert C. Weaver in 1965 House Hearings, pt. I, at 205-06.

66 Circular II $1(\mathrm{c})$. 
generally will announce to the public its need for houses and apartments, and may notify real estate agents and boards, property-owner organizations and the owners of the properties themselves. It can use any form of publicity, including newspaper advertising, television or radio. In Oakland, California, about a third of the unit owners approached the Housing Authority themselves, having heard about the program from other owners, from the newspapers or by word of mouth; about a fifth of the units were known vacancies which the Authority found through its own housing survey; about a fifth stemmed from calls from tenants who wished to be brought into the program in units they already occupied; the rest were obtained through personal contacts of the Authority's real estate negotiators or their friends in the real estate business. ${ }^{57}$ Dwellings offered for use are inspected for suitability to the program and the needs of tenants. When a unit is accepted, the Authority enters into lease arrangements with the owners. ${ }^{58}$ In the case of an owner of a large number of dwellings, a blanket agreement may be entered into which is capable of application to any specific dwelling. ${ }^{59}$

It is true that certain provisions of the Housing Assistance Administration (HAA) guidelines ${ }^{80}$ provide housing authorities with sufficient leverage to make possible a somewhat greater degree of economic integration than otherwise might be possible. However, economic integration is not as simple a concept as it first appears. "Economic integration" is not achieved by finding a subsidized house in a middle-class neighborhood for an elderly widow whose income is a small pension, but who was, and is, culturally a member of the middle class. The leasing program can be, and is, used to subsidize tenants who keep on living where they are. Indeed, as we have said, one of the program's most attractive features is that it does not necessarily demand that a tenant move from his home. ${ }^{61}$ In Chicago, for instance, about fifty per cent of the initial group of tenants were admitted into the leasing program at their request and in their own houses or apartments. ${ }^{62}$ The leasing program, therefore, can tap those of the

57 On Oakland, see M. Melkonian \& P. Whitman, The Leased Housing Program of the Oakland Housing Authority, May, 1967 (unpublished seminar paper, Stanford University Law School). The Oakland Authority plans to use newspaper advertising.

58 Circular $\{\pi$ 7(a)-(d); Address by Marie C. McGuire, Commissioner, Public Housing Administration, Oklahoma Mobilization Housing Conference, Eufaula, Oklahoma, Nov. 7, 1965.

50 Circular $\llbracket 17$.

60 See text accompanying notes 72-73 infro.

61 See Circular $\pi 16$. Compare the unfortunate treatment of an analogous problem in the rent supplement program. Krier, sipra note 23 , at 567 n.83.

62 Telephone Interview with Gene Chmura, supra note 52. The Chicago experience is exceptional. Some cities also "qualify both tenant and unit" in a significant number of cases ( 20 per cent in Oakland), some only occasionally ( 3 per cent in Boston) and some never (Washington, D.C.). 
poor who, for reasons of fear, preference, prejudice or plain common sense, would not like to move into public housing. However, this makes some claims of integration spurious; the leasing program cannot claim to have "placed" the poor in middle-class neighborhoods if it has merely subsidized persons of low income who already live there or who have cultural roots in the neighborhood.

Because of the general tendency of culture lines to follow income lines, the higher the income of the group subsidized, the easier it may be for the unsubsidized middle and lower-middle class to identify with at least the upper fringe of assisted tenants. Maximum income limits in the leasing program show a willingness to accommodate those above the rock-bottom poor. ${ }^{63}$ For example, in San Jose, California, the maximum admission income for a non-welfare tenant family of four is $\$ 4,200$; for continued occupancy, $\$ 6,300 ;^{64}$ and tenants may have assets of up to $\$ 7,500$ ( $\$ 10,000$ if they are elderly). By way of contrast, the net asset limitation in Richmond, California, for conventional public housing is $\$ 2,500 .^{65}$ This differential suggests that those who administer the leasing programs may wish to help the "richpoor"-we might call them the submerged middle class-rather than the hard-core dependent poor, at least for the time being. It is not likely that leasing officials will place an unmarried Negro AFDC mother in leased housing in a solid middle-class white neighborhood. This family will either not be placed at all or will be placed in a neighborhood where it will not arouse attention. In Los Angeles, a

63 It is theoretically easier to raise income limits under the leasing program than under the conventional public housing program, due to the inapplicability of the 20 per cent gap requirement. It should also be easier in fact, since the private landlord has a vested interest in keeping tenants in the program and does not wish to lose the rent guarantee through rising tenant incomes. The possibility and incentive to raise income ceilings for leasing purposes can provide a precedent (that is, an excuse) for making a much needed increase in income limits for the conventional program as well. Thus, it is significant that the leasing provisions invite local authorities to establish higher income limits for the leasing program or to raise income limits generally. See Circular $\pi 5$ (d). One reason not to be overly enthusiastic about this development is the evidence that in at least one region the 20 per cent gap requirement is still being observed. Zollinger Interview.

64 San Jose Housing Authority, Statement of Policies, exhibit 1 (undated). If the family has been displaced by urban renewal or other government action, the maximum income for continued occupancy is treated as a maximum for admission; in other words, a family of four, displaced by urban renewal, is eligible in San Jose even if the family income is $\$ 6,300$. Income is, roughly speaking, gross income less certain deductions from wages (social security, pension, retirement funds or death benefits), child support payments and "predictable medical expenses for a continuing illness ... in excess of $3 \%$ of the aggregate income of the family ... and ... not . . compensated for . . . by insurance." Id. at 20.

65 Statement of Policies Governing Admission to and Continued Occupancy of the PHA-Aided Low-Rent Housing Projects Operated by the Housing Authority of the City of Richmond, California $1, \S 1-\mathrm{A}-6$ (undated).

Not all leasing programs make this distinction. For example, the National Capital Housing Authority, in Washington, D.C., sets the same net asset and maximum rent limits in public housing and in the section 23 program. Telephone Interview with Mrs. Anne Heil, Leasing Acquisition Officer, NCHA, June 1, $196 \%$. 
section 23 staff member stated that where "a woman with six children by six different men applies, we don't want her in section 23 , or even public housing for that matter, since it ruins the Los Angeles Housing Authority's image." ${ }^{68}$ And many cities, though they do not have higher maxima for leasing tenants, do exert special care in their selection, either by a screening process or by giving preference to a trouble-free group such as the elderly. ${ }^{67}$ Thus, the program is likely to maximize integration for those of the poor for whom barriers, though real, are least intractable.

The leasing program is faced, then, with a real but difficult choice: it may follow its inclination to help only the submerged middle class, thereby achieving a small degree of mixture of races and income-groups at the margin; or it may forego any integration at all and devote its attention purely to the housing problems of the very poorest families. A third possible choice-combining the goals of both integration and of improving the housing of the very poor-will be avoided because it is too dangerous politically to be attempted by a new and untried program, which is desperately anxious to "succeed," by achieving limited goals without arousing lethal opposition.

Thus far, the first option-searching out the most "respectable" tenants-seems the clear choice of many authorities. It has been taken, for example, by the Housing Authority in Washington, D. C. The Authority rents mostly rehabilitated homes. Less than ten per cent of the first 139 families placed were headed by women, the Authority claiming that its homes cannot be managed by families with working mothers. ${ }^{68}$ By contrast, a far greater percentage of the families in conventional public housing lack a father; the mothers of many of these families are on welfare and do not work. The reason given by the Authority for barring broken families (and especially unwed mothers) from the leasing program, therefore, seems to be a mere rationalization. Other cities fall into a similar category, as recorded

68 Information on Los Angeles is drawn from David W. Williams, Jr., Report on the Status of Section 23 Housing in the Cities of San Francisco and Los Angeles, with background Commentary on the Housing and Urban Development Act of 1965, May, 1967, at 51 (unpublished seminar paper, Stanford University Law School). Information on Bucks County and Corpus Christi was drawn from telephone interviews with HAA regional officials.

67 In some cities, however, a high proportion of leasing tenants are on "welfare," i.e., receive income from general assistance and AFDC, as distinguished from veterans' pensions, social security, old age pensions and private employment. The line between the two types of income can be roughly taken as the line between the two cultures: that which we call the submerged middle class, and that which we call the dependent or problem poor. In Oklahoma City, for example, only 20 of the first 300 tenants placed were elderly; 70 per cent of the tenant families were headed by women, most of them AFDC mothers. Telephone Interview with Talbert Elliott, Executive Director, Oklahoma City Housing Authority, June 1, 1967.

68 Interview with Mrs. Anne Heil, supra note 65. 
by their eagerness to use the program to benefit the elderly, the lowincome group least likely to offend middle-class neighbors and the chief remaining pool of predominantly white urban poor. ${ }^{69}$

Racial integration is guaranteed, at least formally, by the requirement that the agreement between the local authority and the private owner contain a nondiscrimination clause. ${ }^{70}$ Although the statute provides for tenant selection by the private landlord, ${ }^{71}$ thus apparently making nondiscrimination difficult to enforce, the difficulty has been obviated by the governing PHA Circular. The Circular makes several tenant selection patterns available to the owner: the owner can choose tenants himself, subject to authority approval; he can select from a list supplied by the authority; the authority can select, subject to the owner's approval; or, if the owner prefers, the authority can select tenants without owner approval. ${ }^{72}$ If the owner reserves the right personally to select or approve tenants, the local authority is relieved of the responsibility of paying rent while the unit is vacant, and it may cancel its agreement with the owner in the event he proves too hard to please. ${ }^{73}$ These provisions put teeth into the nondiscrimination clause. An owner who wants the attractive feature of guaranteed rent for empty units between tenants must cede control over tenant selection to the local authority. Of course, the prejudiced landlord simply will elect not to bring his building into the program, as will the landlord who fears that his other tenants will raise serious objections. Consequently, most landlords who enter the program will be those who expect and are willing to accept Negro tenants. Nor will the authorities go beyond the limits of political safety. Although some cities, such as Chicago, report progress in racial integration through leasing, the more common sentiment and fear probably was voiced by a St. Louis staff member who, in discussing the program about to be started in that city, stated that, "We're not going to block-bust."

60 For example, there are programs exclusively for the elderly in Bucks County, Pennsylvania, Corpus Christi, Texas, and virtually all of the leasing in Chicago is for the elderly. Other cities, such as Los Angeles, make a special effort to recruit elderly tenants.

70 Circular $\mathbb{1 0} 10$.

71 The Act provides that "the selection of tenants ... shall be the function of the owner, subject to the provisions of the contract between the Administration and the agency." Housing and Urban Development Act of 1965, $\$ 23(d)(1), 42$ U.S.C. $\$ 1421 \mathrm{~b}(\mathrm{~d})$ (1) (Supp. I, 1965).

$7^{2}$ Circular II 8 (b) (1)-(4). In any case, the local authority determines initial and continuing eligibility, $i d . \pi 8(\mathrm{c})$, and reserves the sole right to give notice to vacate, although it will consider "representations from the owner" in this regard. Id. $\int 8(\mathrm{e})$.

73 Circular $\pi 8($ d). In operation, a general requirement is that if the private owner refuses three tenants sent to him by the authority, the authority may terminate its agreement. Zollinger Interview; San Jose, California Housing Authority, Section 23 Lease \$7. The San Jose lease further provides that the authority is relieved of its responsibility to pay rent if the owner refuses an applicant sent by the authority. Id. 
There is also some danger of covert attempts at discrimination through the use of side agreements between negotiators for the housing authority and private landlords. How this danger will be handled remains to be seen. Some authorities are making a special attempt to place Negroes, or conversely, to bring in some whites so as to avoid an all-Negro program. In Chicago, a far greater percentage of whites are in the leasing program than in conventional public housing-35 per cent as opposed to about 10 per cent. But this type of integration is not everywhere possible. As of June 1, 1967, every tenant placed and virtually every applicant in Washington, D. C., was Negro.

The more radical forms of economic and racial integration have not yet been achieved by the leasing program. Probably no poor, Negro tenants have been placed in wealthy, exclusive white neighborhoods. The rents in these neighborhoods are too high; the leeways permitted by the program's financial formula are not sufficient to permit the leasing of luxury apartments. The program's focus, then, at most, is incremental upgrading of neighborhoods; perhaps nothing more is desirable at the present time. What is needed is decent housing in decent areas, not a bold leap across all the visible and invisible lines of class, caste and status in America. Given the choice, many tenants will not wish to leave neighborhoods where they feel culturally comfortable. In many cities, integration means moving Negro poor away from the core of the city, where many of them have jobs and friends. On the other hand, some of the poor, who work in the suburbs, would be better off living closer to their jobs, at least until transportation problems between the city and the suburbs can be solved. ${ }^{44}$

Some cities are striking a happy medium between concentrating on hard-core slum areas that are physically unsafe and irretrievably substandard, and fashionable neighborhoods which cannot be feasibly tapped. For instance, a leased house in Washington, D. C., "must be a place where young children will be safe; it should have a fenced yard, or a playground nearby, where you don't have to cross a major street." This criterion eliminates "the worst sections." 75 New York City will not accept "a single building that's been rehabilitated in a slum block; it can't stand by itself in the neighborhood. Unless there are plans to upgrade a big area, why, we won't go in." 76

Neighborhood objections are perhaps the most serious brake on the prospects for achieving any significant degree of racial or economic

74 In Los Angeles a federally subsidized bus line has been inaugurated for the Watts district. A novel extension of the system is anticipated: "the car-pool idea applied to buses." N.Y. Times, March 5, 1967, at 57, col. 1 .

75 Telephone Interview with Mrs. Anne Heil, supra note 65.

76 Telephone Interview with Harold Sole, Chief, Leasing Division, New York City Housing Authority, June 2, 1967. 
integration through leasing. Owners often are prejudiced themselves or have prejudiced tenants or neighbors. Upper-class and middle-class neighborhoods, even when they have shed their overt racism, fear invasion by the poor. America has a long and ignoble history of neighborhood action to discourage such invasions-particularly if the invaders are Negroes. ${ }^{77}$ The house located in the middleclass suburb or the unit in the middle-class apartment building cannot be offered without fear of reprisal or resentment. A San Francisco plan to place section 23 tenants in a cooperative middle-income project ${ }^{78}$ had to be abandoned when a reporter "leaked" the news, and tenants objected violently to the presence of "such trash" in their building. These factors, of course, are less likely to operate in areas already occupied by the poor or by racial minorities. In these areas, integration depends upon attracting some low-income whites or the lower middleclass into the neighborhood. To the extent that leasing encourages physical rehabilitation, some slight population movement of this sort may occur.

The white middle class is conscious of status and is worried about its financial investment in homes, schools and neighborhoods. The poor are considered a threat. ${ }^{7 \theta}$ A primary tool in the fight for integration, therefore, must be secrecy. Under the leasing program there is no requirement that participant dwellings or tenants be identified. ${ }^{80}$ Secrecy is difficult, but not impossible, to achieve if proper precautions are taken. The housing authorities studied have been quite careful to preserve the anonymity of their tenants. ${ }^{81}$ The very fact that tenants are placed in middle-income housing or neighborhoods rather than in large, easily recognizable public housing projects contributes to the chance for success. But secrecy can only be achieved at the cost of some integration. The identity of a tenant can be concealed only if the tenant is no more than marginally different from his neighbors. An unemployed Negro woman with no husband, many children, poor furniture and threadbare clothing for her family obviously does not "belong" in a middle-class neighborhood. Secrecy, therefore, requires an emphasis on the submerged middle class. It means integration for

77 Thoroughly and passionately chronicled in C. ABRAMs, Forbidden NEIGHBors (1955). But see N.Y. Times, March 12, 1967, at 53, col. 1; San Francisco Sunday Examiner \& Chronicle, Nov. $27,1966, \S 1$, at 29 , col. 1.

78 To be financed under 12 U.S.C. \$1715 (Supp. I, 1965).

79 An association of building material dealers objected to the leasing program, on grounds that it would "interject public housing in practically any area of a city," and might affect "the value of surrounding homes in the area." 1965 House Hearings, pt. II, at 1111 ; 1965 Senate Hearings 518 . The objection, of course, is not really to buildings, but to tenants.

80 McGuire Address.

81 Anonymity is so thorough in some areas that a program tenant can obtain credit at the neighborhood grocery. Zollinger Interview. 
those most easily integrated. Perhaps that is all that can be expected. If the cultural gap between tenant and neighbor is too great, the program will have achieved placement, but not integration, in the fullest sense. A Negro tenant can be ignored and scorned by his neighbors and driven into a private ghetto of his own which is far lonelier than the slum. Some cities report that Negroes "just won't go" into all-white middle-class neighborhoods. The claim may cover up some covert discrimination; yet it is plausible. Leasing cannot solve the problems raised by major cultural gaps between groups in our society. At best it may make possible small inroads and incremental improvements.

\section{B. Expanding the Prerogative of Choice}

Conventional public housing in the big cities has been condemned for its dismal uniformity. ${ }^{82}$ But the prospective tenant must choose project life or forsake any housing subsidy. Tenants must move away from friends, ethnic ties, a job or their children's schools to gain housing assistance. Large projects are unfriendly and cold in appearance and easily identified as the local "poor house." High-rise living has peculiar hazards for families with small children. ${ }^{83}$ Big families are almost impossible to place, since financial limitations make it difficult to build large units in conventional public housing. ${ }^{84}$

Some cities have gone into the leasing program in order to solve precisely these problems. Thus, at the time Omaha, Nebraska, embarked on its leasing program, it faced the problem of applicants who needed four- or five-bedroom apartments. There were none in the city "fit to live in," and there were none available in conventional public housing, although vacancies in two-bedroom apartments were frequent. $^{85}$ In some places, it was felt that leasing might tap a group of people who objected to project life. Still other cities hoped leasing would put an end to the conventional high-rise "project," substituting a program of broader choice for the tenants. The very structure of the program-its scattered housing feature-hopefully would contribute to the solution of problems of location. There was bound to be wider

82 See, e.g., C. Abrams, The City is the Frontrer 30-31, 268-69 (1965).

83 E.g.: "[Mothers worry] lest a small child might try to emulate Superman and take wing from the tenth floor. Indeed some do so, without success. Sometimes even the most thoroughly toilet-trained youngster cannot make it from playlot to bathroom-which does not help the elevator." Id. at 30 .

84 Aronov \& Smith, Large Families, Low Incomes, Leasing, 22 J. Housing 482 (1965). See also C. Abrams, THe CITY Is THE FrontiER 46, 269 (1965).

85 Interview with F. A. Warren, Project Manager, Omaha Housing Authority, Aug. 12, 1966. Omaha applied for a 100-unit pilot program. By the end of May, 1967,55 families actually had been placed in leased housing. 
dispersion of housing and a wider spectrum of neighborhood alternatives than in the conventional program.

Some of these hopes have been at least partially realized. In many cities, tenants are asked where they want to live and every reasonable effort is made to place them there. Tenants may even have the freedom to seek out interested landlords on their own initiative. In the cities studied, there is impressive evidence of beneficial results from the new tenant prerogatives. Certainly this is true as to large families shut out of conventional public housing, and as to whom demonstration programs had indicated that leasing would be of help. In Washington, D. C., a family of seven, living in a "dark, damp one-bedroom apartment that flooded with an inch or more of water when it rained," so was placed in a six-room house in a pleasant neighborhood and "is now an active member of the neighborhood block improvement club." 87 A family of eleven, living in a dismal basement apartment where "hanging sheets and blankets served as partitions to provide some degree of privacy," 88 was rehoused in an eight-room dwelling, and now maintains "the best looking front yard in the block." so In Boston, a family of 13 has been placed in a decent home under the leasing program. And freedom of choice is certainly maximized for those Chicago tenants who gain subsidies by staying exactly where they are. Many of these are elderly, some of whom had been skimping on food and other necessities to keep up the rent they could barely afford.

Abandoning the project concept makes possible the use of a varied inventory of dwelling types-large and small apartment buildings, rowhouses, individual dwellings and duplexes. Tenants can be given housing suitable to their individual needs. Families with small children can avoid high-rise buildings. The elderly can choose locations which assure company in times of loneliness, assistance in case of emergency. Even satisfaction of individual aesthetic tastes is possible, at least theoretically, under the leasing program. In many cities studied, tenants are shown apartments and homes available under the program and, within limits, given a second choice, if the first unit shown to them proves unacceptable. Although a hypercritical attitude would cost a potential tenant his chance in the leasing program, freedom of choice is vastly greater than in the conventional program. Chicago is particularly liberal in this respect. If it is feasible, the Chicago Authority gives the tenant three addresses located in a neighborhood of the tenant's own choosing. He is advised to "look at the building,

86 Aronov \& Smith, supra note 84 , at 483 .

${ }^{80}$ Id. Cf. 1965 Honse Hearings, pt. II, at 599. 
look at the apartment, look at the neighborhood" before making his choice. If none of the three addresses proves suitable, the Authority may give him three more referrals. "Some people are just hard to satisfy; we tell them, OK, you can go out on your own, and find something, and if it qualifies, why, maybe we can work it into the program." ${ }^{90}$ Other cities, because of the exigencies of the housing market or for reasons of policy, do not encourage the finicky, sometimes effectively giving the prospective tenant only one choice.

The new freedom of choice, however, suffers the same limits as the rest of the program. More freedom of choice is granted to those who are found most suitable by the local authorities. The elderly, for example, are both more choosy than the non-elderly, and are catered to much more by the local authorities. It is probably no coincidence that the Chicago program, which is so permissive with regard to tenant wishes, is overwhelmingly for the old. Perhaps the psychological needs of old people are greater than those of the young; the shock of a new neighborhood and totally new surroundings would be hard for the elderly to take. In any event, it remains true that the more "middle class" a tenant's cultural background, the more freedom of choice the leasing program affords. At the one extreme is the elderly white pensioner; at the other, the Negro AFDC mother. Despite this, however, it must be conceded that section 23 housing grants more freedom of choice to more potential tenants than does conventional public housing, which grants little freedom or none at all. ${ }^{91}$

\section{The Leasing Program and the Housing Supply}

Leasing will be applied almost exclusively to existing housing. ${ }^{92}$ It is supplemental to the conventional public housing program, ${ }^{93}$ which

90 Telephone Interview with Gene Chmura, supra note 52.

91 In theory, conventional public housing could afford potential tenants some freedom of choice, if the local authority had a number of projects of various types and in various locations. Some housing authorities have been trying to maximize racial integration and to expand freedom of choice by this means. See, e.g., N.Y. Times, June 2, 1966, at 25, col. 3.

Leasing also permits options whereby tenants may purchase their dwellings when income permits, thus further enhancing the prerogative of choice. Circular $\mathbb{1 1} 13(\mathrm{a})$. An option to purchase is significant when we take into account the findings in one demonstration program that the income of leasing tenants showed substantial increase, due "to the better housing, which eliminated emotional uncertainties among the family breadwinners and gave them new incentives." N.Y. Times, Jan. 8, 1967, at 64 , col. 1 .

92 Address by Joseph Burstein, General Counsel, Public Housing Administration, 30th National Conference of the National Association of Housing and Redevelopment Officials, Philadelphia, Pennsylvania, Oct. 26, 1965. "The rent supplement program, in contrast, is generally limited to new construction. See Krier, supra note 23, at 558 nn.29, 30 .

83 Housing and Urban Development Act of 1965, \$23(a) (1), 42 U.S.C. \$1421b (a) (1) (Supp. I, 1965); 1965 House Hearings, pt. I, at 205; 1965 Senate Hearings 77. 
concentrates on construction of new projects. The "Flexible Formula" financing device makes utilization of existing dwellings possible. ${ }^{94}$ This device frees federal contributions from the rigid formula applicable to new construction of public housing. ${ }^{95}$ Under the conventional program, annual federal contributions amortize capital costs over a long periodgenerally forty years. ${ }^{96}$ This method would be inappropriate for the leasing program, which works on a short-term basis and requires no appreciable initial outlay. ${ }^{97}$ Under the new formula, the annual federal contribution that would be required to support a unit of newly constructed housing (that is, to pay principal and interest on the bonds which would have to be floated) can be used as the basis for computing the annual subsidy available for a unit in the leasing program. ${ }^{98}$ While the federal contribution can be no greater than that under the conventional program, leasing is likely to afford tenants better housing. The cost of obtaining existing housing will generally be lower than the cost of newly constructed dwellings, despite the fact that leased housing pays full real estate taxes rather than the "in lieu" payments of conventional public housing. ${ }^{99}$

94 Housing and Urban Development Act of 1965, §502, 42 U.S.C. $\$ 1410$ (c) (Supp. I, 1965). Implementation of the flexible formula is explained in PHA Circulars dated Oct. 12 and Dec. 2, 1965.

95 McGuire Address. See also 1965 Honse Hearings, pt. I, at 203.

${ }^{26}$ See generally 1965 House Hearings, pt. I, at 203-05; 1965 Senate Hearings 75; Committee Print, supra note 27, at 118.

971965 House Hearings, pt. I, at 204; 1965 Senate Hearings 75.

98 Housing and Urban Development Act of 1965, \$502, 42 U.S.C. $\$ 1410$ (c) (Supp. I, 1965); Id. \$23(e), 42 U.S.C. \$1421b(e); Circular $\pi 4(\mathrm{a}) ; 1965$ House Hearings, pt. I, at 204-05; 1965 Senate Hearings 75.

PHA Circular, Oct. 12, 1965 [hereinafter cited as Financial Circular], illustrates how the formula would work. Assume that in a given area of the country, the costs of constructing public housing units are such that each two-bedroom unit would cost $\$ 15,000$ to develop. This sum is then multiplied by a figure, $4.58 \%$, which, for the period in question, has been based on "interest rates achieved on 40-year bonds sold by Local Authorities." This gives a fixed annual contribution rate of $\$ 687$ per unit. Dividing this figure by 12 , we obtain a figure of $\$ 57.25$ per month, available as a subsidy for two-bedroom units in the leasing program. Note that the flexible formula does two things: it provides a basis for computing the subsidy, but at the same time it puts an effective ceiling on monthly subsidy payments per unit. 1965 House Hearings, pt. I, at 205. See also 1965 Senate Hearings 77. The tenant's rent, then, must be sufficient to make up the difference between the federal contribution and the cost of the dwelling to the local authority (rent paid to the private owner plus administrative expenses). This difference- the tenant's rent-will generally be twenty to twenty-five per cent of his income. Circular $\llbracket 5(\mathrm{a})$. "Consideration must also be given to the cost to the tenant of heat or other utilities which will not be provided by the owner." Id. The Flexible Formula Fixed Annual Contribution Rate will be fixed twice a year by PHA, in June and December. Financial Circular I2(4)c. Local authorities may also submit proposals based on other computation methods, if the recommended procedure "does not result in a reasonably accurate estimate of the fixed annual contribution that would be established for the type of newly constructed project that the Authority would be most likely to undertake to house the number, sizes, and kinds of families to be housed in the proposed project utilizing the flexible formula." Financial Circular $\mathbb{1} 3$.

99 Zollinger Interview. See 42 U.S.C. $\$ 1410(\mathrm{~h})$. This statutory provision, in essence, exempts public housing projects from local personal and real property taxes, 
Since it uses existing housing, the leasing program can move faster than the conventional program. New construction involves a painfully slow and complex process of finding and obtaining sites, gathering bids for design and construction and floating bonds, in addition to the actual matter of putting up the project itself. Sometimes as many as five years elapse between the planning of a project and its completion..$^{100}$ Leasing, on the other hand, can go into operation almost immediately; ${ }^{101}$ Representative Widnall, sponsor of the program, saw this as one of its best features. ${ }^{102}$ Speed also is encouraged by the fact that the requirements of a "certified workable program for community improvement," and a "cooperation agreement" between the local government and local authority, are not applicable to leasing, ${ }^{103}$ although both are required under the conventional program. ${ }^{104}$ All that is necessary is a resolution by the local governing body approving the leasing program for its jurisdiction. ${ }^{105}$ It is also impressive that some units of local government without any conventional housing program (and often politically unlikely to approve such housing) have gone into leasing. This includes some good-sized cities (Wichita, Kansas; San Jose, California), Bucks County, Pennsylvania, and tiny Elsa, Texas, which has applied for twelve units.

but requires instead that the local authority must make "payments in lieu of taxes equal to 10 per centum of the annual shelter rents charged in such project," or less if state or local law so provides. Section $1410(\mathrm{~h})$ is explicitly inapplicable to leased housing. 42 U.S.C. \$1421b(f); Circular $\llbracket 3(\mathrm{~b})(1)$.

1001965 Honse Hearings, pt. II, at 796. The result, of course, is long waiting lists for conventional public housing. See 1965 House Hearings, pt. II, at 816 . See also 1965 Senate Hearings 314-15, 318. "Turn key" public housing, of course, is faster than conventionally built public housing.

101 Inspiring the label "instant housing." See, e.g., Address by Marie C. McGuire, Commissioner, Public Housing Administration, Oklahoma Mobilization Housing Conference, Eufaula, Oklahoma, Nov. 7, 1965. ings 75.

1021965 House Hearings, pt. I, at 457. See also, id. at 203; 1965 Senate Hear -

103 See Housing and Urban Development Act of 1965, §23(f), 42 U.S.C. §1421b(f) (Supp. I, 1965); Circular \3(b)3. (1963). 10442 U.S.C. $\$ \S 1410$ (e), 1451(c) (Supp. I, 1965); 42 U.S.C. $\$ 1415(7)$ (b)

105 Housing and Urban Development Act of 1965, §23(a) (2), 42 U.S.C. §1421b (a) (2) (Supp. II, 1967); Circular I 3 (a). The requirement of local approval by resolution originated in the conference substitute bill. Committee Print, supra note 27 , at 304. A similar requirement came into the rent supplement program by way of a rider to a supplemental appropriation act. See Krier, supra note 23 , at 556 n.15.

In California, article XXXIV of the Constitution, adopted in 1950, provides that "[n]o low rent housing project shall hereafter be developed, constructed, or acquired in any manner by any state public body until a majority of the qualified electors . . approve such project by voting in favor thereof. . ." Passage of this amendment was a victory for the anti-public housing lobbies; since 1950 , projects cannot be built without a referendum, which the proponents of public housing frequently lose. The provision, however, has been construed not to apply to the leasing program. 47 OPS. CAL. ATT'Y GEN. 17 (1966). This is a tremendous advantage for the leasing program, if for no other reason than that communities can embark upon a program without a costly and time-consuming referendum. 
However, it does take time to prepare an application, conduct the necessary real estate surveys, gather a staff, obtain an appropriation and get the program started. Effectively, over a year and a half has passed in which local authorities might have gone into the "instant housing" business. The results have not been quite so instantaneous as might have been hoped. As of June 1, 1967, New York (the giant of conventional public housing) and Chicago each had less than 500 units under lease; such major cities as Philadelphia, St. Louis, and Detroit had not yet placed a single tenant; cities such as Dallas and Seattle had no intention of applying. ${ }^{106}$ California and some parts of the East coast had moved the fastest and gone the furthest; but an official in Philadelphia admitted that the program had not "set the world on fire" in his region. As of May 1, 1967, the entire Chicago region, which had over 100,000 units in the conventional program, had 859 units occupied by section 23 tenants. ${ }^{107}$ Some housing authorities were leary of the program, perhaps simply because it was new and untried. Others were waiting to see how it would turn out. But a flock of applications in the various regional offices attests to the fact that the program is beginning to catch on. There remains the question of the actual pace of operation. The Boston program placed its first occupant in a leased apartment on October 1, 1966, but only 109 tenants had been placed by May 31, 1967.108 Yet, Boston's interesting and admirable program has not been unusually slow by any means; its pace is, for example, almost double that of Omaha, Nebraska. The typical leasing staff is small, procedures have not been worked out in full detail in some cities, and the process of matching tenants and landlords is not entirely painless. All in all, though leasing avoids the long delays of construction inherent in the conventional program, it has not yet proved its full capacity for speed.

Leasing's focus on existing housing has been criticized on the ground that the program will not add to or improve the housing supply, and that it will "just be using what is available." 109 There is some merit to this charge. But it was hoped that the program would place major emphasis on rehabilitation of substandard dwellings. ${ }^{110}$ The legislation allows for rehabilitation ${ }^{111}$ and the federal adminis-

108 Information from various regional offices of HAA, and, in some cases, from the local housing authorities.

107 Telephone Interview with William Miller, Chief, Leased Housing Division, Region IV (Chicago), June 2, 1967.

108 Interview with Frank Powers, supra note 13.

1091965 Honse Hearings, pt. I, at 456. See also, id. at 457; Note, Govermment Housing Assistance to the Poor, 76 Y ALE L.J. 508, 543-44 (1967).

110 See, e.g., Address by Marie C. McGuire, Commissioner, Public Housing Administration, Houston Apartment Association, Houston, Texas, Jan. 18, 1966.

111 Housing and Urban Development Act of 1965, §23(c) (1), 42 U.S.C. $\$ 1421 \mathrm{~b}$

(c) (1) (Supp. I, 1965) (units which "are, or may be made, suitable for use as low-rent housing..."). 
trators of the program are "particularly interested in encouraging this type of leasing because of its obvious benefits over simply leasing housing which already meets the necessary standards." ${ }^{112}$ Since the program is decentralized in operation, and offers no concrete aids to rehabilitation, whether upgrading will result depends almost entirely on the particular policies and plans of specific local authorities. There is evidence that the program has stimulated investment in the upgrading of property in many cities. In a number of instances landlords have responded to the incentive of a federally-guaranteed lease and made repairs either to bring their properties up to code, or to improve the appearance or facilities of their holdings. In Washington, D. C., demonstration program rehabilitation expenditures averaged $\$ 1,500$ per dwelling. All fifty dwellings brought into the program underwent some rehabilitation, ${ }^{113}$ and the emphasis on rehabilitation has continued. Of 139 units under lease in Washington as of June, 1967, 80 are four-bedroom, 19 are five-bedroom, 13 are six-bedroom units; virtually all of these are private dwellings, and virtually all of them have been rehabilitated, reconverted and restored. In Washington, redecoration is the minimum required of the owner. In this and other cities, the Authority gives prospective program-landlords a letter of intent to lease, which helps them in raising money to finance rehabilitation.114 In Boston, too, "there's always something to be done-electricity, a little plumbing, painting and things like that. The minimum is painting." ${ }^{115}$ In Oakland, 28 per cent of the first units leased were substantially rehabilitated and another 40 per cent received minor repairs. ${ }^{116}$ Other cities, however, such as Chicago, do not stress rehabilitation; most of the units that come into these programs are already standard.

The program clearly can and does expand the number of standard units available to the poor. But the incentives to rehabilitate, though real, are relatively small. One simply cannot imagine that the leasing program, in itself, can make major changes in the hard-core slums. The subsidy is not great enough to induce the owner of a decaying old-law tenement in New York to bring his building up to standard; as a

112 Circular $\pi 12$ (b). To meet the required standards, units must be "decent, safe, and sanitary"; the exterior and interior of the building must be in good condition; the unit must have adequate private cooking and sanitary facilities, and adequate heating, lighting and ventilation; the unit must be large enough for the family occupying it; the unit must be located in a decent neighborhood reasonably accessible to public transportation, schools, churches and stores. Circular $\pi 11$ (a).

113 Aronov \& Smith, supra note 84, at 484.

114 Interview with Mrs. Anne Heil, supra note 65.

115 Interview with Frank Powers, supra note 13.

116 Melkonian \& Whitman, sitpra note 57. 
result, cities like Washington, D. C., and New York do not even attempt to rent in rock-bottom slum neighborhoods.

The number of standard units that can be made available is not unlimited, and funds are exhaustible. There has been concern, moreover, that the program has the potential to increase rents, at least in the short run, by consuming a great deal of a community's stock of housing. ${ }^{117}$ To date, there has been no evidence of such a rise in rents. In some cities, far from experiencing a rise in rent costs, negotiators for the housing authority have been able to reduce rents to below pre-leasing program levels. Backed up by the guarantee of long-term leases, Oklahoma City has been renting three-bedroom apartments for $\$ 95$ that might cost as much as $\$ 125$ a month on the open market.118 Other cities, too, report that they have been able to rent units for approximately 10 per cent less than the rents at which the units previously had been rented. These figures are all the more impressive when one realizes that rent reduction has often been accompanied by an increase in the quality of the leased units.

Fear of a general rent rise, however, cannot be allayed entirely by experience over so short a period of time, and the government is still extremely sensitive to the danger. The 1965 PHA Circular announced that

[a] proposed leasing program which would reduce [the] . . . vacancy rate to less than 3 per cent for any unit size will not be approved unless the Local Authority satisfies the PHA that the leasing program will not have a substantial inflationary effect on the private rental market or that the program is justified by the exigencies of a particular situation, such as a critical immediate need for relocation housing. ${ }^{119}$

The community applying for a leasing program must provide supporting data to show that the result of the program would not be to leave less than three per cent of the available housing unoccupied. ${ }^{120}$ The limitation, however, does not really impose a straight-jacket on the cities. It is not easy to measure a vacancy rate and, conversely, it is

117 See, e.g., 1965 Honse Hearings, pt. I, at 205; id. at 816; Zollinger Interview. 118 Interview with Talbert Elliott, supra note 67. Other cities, however, rent at or near market, either because they are unable to get more favorable terms, or because they do not try. In Chicago, the Authority has paid an average of $\$ 96$ a month for one-bedroom units, which the Authority feels is about the market rate, though the Authority sometimes can "push and pull a bit" in negotiating with landlords. Interview with Gene Chmura, silpra note 52.

119 Circular $\int 1$ (b) ; the 3 per cent provision is inapplicable to rehabilitated housing, however. "Since such rehabilitation increases the standard housing supply, it would clearly not have an inflationary effect upon the private market." PHA Circular, Dec. 2, 1965, supplementing Circular II 1(b).

120 See HUD Form, Application for a Low-Rent Housing Program and Supporting Information, pt. II, at 1 (1967). 
not hard to manipulate the data to prove that there is a vacancy rate greater than three per cent in some classification of units. At least one city, it was confidentially reported, may have done so. And Chicago's first application for 500 units was approved, even though it showed an overall vacancy rate of only 2.67 per cent, since the vacancy rate was much higher in certain low-income "pockets" in the city. ${ }^{121}$ There are limits, however, to the flexibility of this guideline and a low vacancy rate may also evoke low enthusiasm for leasing on the part of the housing authority and local real estate people. Seattle has a 0.9 per cent vacancy rate and does not plan to take part in the program. ${ }^{122}$

In the long run, the leasing program ought to improve the supply of housing for the poor, since it reduces the landlord's risks and provides a large stable market for housing. There is some danger, however, that communities will lose interest in any form of public housing other than leasing and that Congress will divert its appropriations to leasing, rather than to new construction. This does not appear likely, especially in the light of the enthusiasm for "turn-key" housing, which does provide new construction. But in some communities leasing may drive out new public construction. Should this occur, the amount of new public construction foregone will have to be subtracted from the amount of new private construction stimulated by the increased demand, in order to arrive at a true net long-term figure.

There also may be some danger of over-rehabilitation and displacement of low-income tenants from some neighborhoods. The leasing program hopes to bring about general improvement of neighborhoods. ${ }^{123}$ In the past, neighborhood rehabilitation and urban renewal programs have often driven out low-income tenants. ${ }^{124}$ A renovated

121 Interview with Gene Chmura, supra note 52. There had been concern that leasing would be of little help to New York City, which has a housing shortage. 1965 Senate Hearings 800 . A program has been approved for that area, however, in spite of the fact that the city's vacancy rate is about 2 per cent. See Note, Govermment Housing Assistance to the Poor, 76 YaLE L.J. 508, 513 (1967).

122 Telephone Interview with Director, Seattle Housing Authority, May 31, 1967.

123 Circular $\mathbb{1} 12$ (c).

124 See generally C. Abrams, The City is the Frontire 132-54 (1965). The problem of tenant dislocation, among others, was poignantly treated last year in the excellent CBS Documentary, "The Tenement," CBS Television Network, Feb. 28, 1967, describing tenement life in Chicago: "MRS. BARBER: We will have to move - start looking for a place but they didn't say when, you know. But-and I still don't know, you know, how long we have here. MR. BECKWITH: They told me they was going to find me a place. They axe [sic] me what I wanted to live at, in a project or out of project . . . I say, well, I say I wouldn't mind taking a project, I don't guess. They say, well, we're sending an application to you to a project then .. MRS. JOHNSON: In a way, I'm glad to leave, in a way. In another way, I'm sorry. When you've lived in a place a long time-had two kids born in that. place-that place really have a hold over you and the kids-my little boy-eight years old-he just love it. He just loves his little friends. He feels like he's lost nowand that's what really makes me feel really sad to leave the place." 
area becomes attractive to middle and upper classes, and rents rise along with the quality and desirability of the neighborhood. Georgetown is a classic example of a neighborhood that became too rich for the poor. It is true that, under leasing, rehabilitation is carried out expressly for the low-income tenant. ${ }^{125}$ But, as the leasing subsidy begins to improve the quality of housing in an area, unsubsidized owners might improve their properties because of neighborhood pressure or the speculative belief that the neighborhood will eventually be attractive to higher income tenants. Ultimately, unsubsidized tenants might have to leave. In at least one of the demonstration programs, some owners refused to join in the leasing venture, hoping that a major rejuvenation of the neighborhood would increase the value of their holdings. ${ }^{126}$

So far, however, the danger from over-rehabilitation seems remote, and the demonstrable benefits of section 23 seem to outweigh these largely hypothetical detriments. These benefits include, of course, the amount of money spent on rehabilitation, painting, decorating and general improvement of property. Much of this money would not otherwise have been spent. Generally, governmental policies towards slum landlords have been highly punitive. Health and housing laws impose costly requirements on the landlord without a subsidy, on the unexamined assumption that there are huge, hidden profits out of which these costs can be met. ${ }^{127}$ Section 23 tries a radically different approach by indirectly subsidizing rehabilitation. The subsidy, of course, is the guaranteed rent, the long-term lease and public responsi-

125 Under the program, families cannot be permanently displaced in order to provide units. Circular $\pi 16$. In some cities, in fact, leasing has provided a solution to the problem of finding relocation housing for families displaced by other governmental programs. Of course, rehabilitation of occupied dwellings will normally involve temporary displacement. Such rehabilitation can occur under the provisions of the leasing program. Some attempts at rehabilitation while tenants remained in their dwellings have proved to be almost disastrous to tenant comfort. Old Building + Low-Income Tenants + Profit-Seeking Rehabilitation, 24 J. Housing 28, 31 (1967). In the case of mass rehabilitation, which might be possible to a limited extent under the leasing program, prefabrication techniques make possible total renovation of a large apartment building in 48 hours, with minimum inconvenience to tenants. See TIME, April 21, 1967, at 60 . Rehabilitation under the program probably will proceed more often on a small, individual basis; it will not take advantage of the techniques and economies of scale possible in the mass effort. There have been cases, however, of substantial renovation under section 23 . In Washington, D.C., 54 2-bedroom units in a private development were converted into 27 4-bedroom units and put under lease. Interview with Mrs. Anne Heil, supra note 65.

126 Aronov \& Smith, supra note 84, at 485.

127 This subject is treated in some detail in L. FRIEDMran, GovERnMrent and Slum Housing: A Century of Frustration (1968). See also A. Schorr, Slums

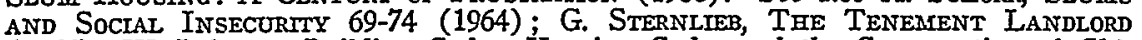
(1966); W. Lehman, Butilding Codes, Honsing Codes and the Conservation of Chicago's Housing Supply, 31 U. CHI. L. REv. 180 (1963). For a specific example of the unprofitability of a hardcore slum tenement, see W. KLEIN, LET IN THE SUN $141-68,273-74$ (1964). Subsidies are available to the poor to rehabilitate their own homes, under certain circumstances. See Housing and Urban Development Act of $1965, \$ 106(\mathrm{a}), 12$ U.S.C. \$1701s (1965). 
bility for the condition of the premises. In many cities, such as Washington, D. C., rehabilitation is the heart of the section 23 program and the subsidy seems to be producing the desired results; in others, it is a welcome by-product. Moreover, in some cities, leasing has brought the additional benefit of a quick and humane solution to the agonizing problem of finding relocation housing for the dispossessed.

Closely related to general neighborhood improvement is the possibility that rehabilitation will "meet the urgent housing needs for families who wish to remain in the neighborhoods where they now reside." ${ }^{128}$ Some will view this aspect of the program as most appealing to persons with ethnic ties to their neighborhoods; on the other hand, it will be criticized as a means to "perpetuate racial ghettos by offering dwellings in neighborhoods that are frequently dominated by one ethnic group." ${ }^{28}$ The primary evil of the ethnic neighborhood, however, is that its inhabitants are often unwilling prisoners in substandard housing. The free choice of people to live in an ethnic neighborhood should not require that they simultaneously surrender their claim on decent housing. Low-income neighborhoods with decent housing and willing tenants add variety to urban living and bring positive benefits to their residents.

\section{The Dilemma of Decentralization: Leasing and the Allocation of Governmental Power}

The Housing and Urban Development Act of 1965 has been hailed as a new and different way "to get at the core of our national ailment by cutting through and shaking up the traditional patterns and practices of providing governmental assistance." 130 With respect to low-income housing, the new pattern emphasizes greater cooperation with private enterprise. This cooperation is considered a value in itself by many members of Congress and the general public. Furthermore, it is economical: a dollar of private enterprise looks like a dollar of tax money saved. The search for cheap subsidies has deep roots in housing history. Housing codes and tenement house laws are, among other things, attempts to force landlords to upgrade their property without any public expense other than the cost of policemen and inspectors. ${ }^{131}$

1281965 House Hearings, pt. II, at 583.

129 Cf. Mulvihill, Problems in the Management of Public Housing, 35 TEMr. L.Q. $163,192(1962)$.

130 Burstein, supra note 92.

131 The section 221 (d) (3) below-market-interest-rate program, see generally Note, Govermment Housing Assistance to the Poor, 76 Y ALE L.J. 508, 515-18 (1967), enacted in 1961, and primarily of benefit to the lower middle-class, was another bid for cut-rate stimulation of the private market. The embattled rent supplement program also strongly reflects government's desire to stimulate private investment. See Krier, silpra note 23 , at 559 . 
The leasing program has been described as part of the new "allout public-private joint attack on poor housing." 132 Administration of the leased housing program demands that local authorities work closely with builders and developers, realtors and dwelling owners. The federal administrators "want private homebuilding and rehabilitation segments of the industry to become involved on a massive scale." 133 A new "partnership" 134 between the local authority and private interests in the community is to come into being. The public-private relationship may "range from the responsibilities and mechanics of managing properties, and more importantly-the problems and responsibilities of dealing with the disadvantaged in our communities. The latter may be a whole new experience for the private owners-or, at least new in the sense of involvement with the public interest." 135 The new relation of the local authority to the community "will establish communication between private housing and public and quasi-public efforts and tend to break down the unrealistic division between the private and public housing market." ${ }^{138}$ This increased communication, it is said, will make the public low-income housing sector more efficient. "Public housing has suffered because it has been estranged from the entrepreneurs and mechanisms which have been honed to the sharpest edge by the abrasions of competition in the private market." 137 Thus, it is hoped that rehabilitation, spurred on by leasing, will provide a "laboratory . . . for private industry to help shape and hone the patterns and techniques, the criteria and procedures, of a new and obviously needed industry." 138

But reliance on private enterprise is not an end in itself. The ultimate goal, presumably, is the creation of an adequate supply of decent housing for the poor. Giving private enterprise an important role can be justified if it tends to increase the housing supply or to remove political or social impediments to improvement of the supply. Certainly, the political benefits of the partnership are striking. Real estate interests have fought public housing bitterly for decades. In

132 Burstein, supra note 92.

133 Address by Marie C. McGuire, Commissioner, Public Housing Administration, Oklahoma Mobilization Housing Conference, Eufaula, Oklahoma, Nov. 7, 1965.

134 McGuire Address, supra note 45.

135 Address by Marie C. McGuire, Commissioner, Public Housing Administration, Houston Apartment Association, Houston, Texas, Jan. 18, 1966.

138 Address by Marie C. McGuire, Commissioner, Housing Assistance Administration, Annual Convention of the National Municipal League, St. Louis, Missouri, Nov. 15, 1965.

137 Address by Marie C. McGuire, Commissioner, Public Housing Administration, National Association of Housing and Redevelopment Officials, Philadelphia, Pennsylvania, Oct. $25,1965$.

138 Id. 
California, they have led the struggles which have killed public housing in many referenda. But real estate interests have not opposed section 23 housing. Indeed, they applaud it. In city after city, officials report the cooperation and outright enthusiasm of real estate boards. Many administrators in the leasing program are themselves real estate men, brokers and real estate lawyers; they speak the language of their trade, and they communicate easily with their fellows in the business. Leasing, in some cities, has come to the rescue of foundering real estate ventures. Thus, in St. Paul, Minnesota, section 23 took over 101 units in a middle-income project for the elderly which was having trouble finding enough tenants, and in Holyoke, Massachusetts, it saved a dying hotel. ${ }^{139}$ By co-opting landlords and brokers, the program has achieved a degree of popularity unthinkable for public housing. This popularity, it is true, has been purchased at a price-the three per cent vacancy-rate limitation ${ }^{140}$ is one example-but to date the price seems not to have proved excessive.

Another form of co-optation is also inherent in the leasing program. The leasing program was intended to present a challenge to local authorities and to give them a chance--perhaps their last chanceto "prove themselves." 141 Unlike the rent supplement, leasing is administered through the Housing Assistance Administration (formerly the Public Housing Administration), and is run by local public housing authorities. It is subject to the control of municipal government and the local authorities. There are some clear gains from this arrangement. Section 23 is acceptable to NAHRO and the public housing bureaucracy; ${ }^{142}$ even in old-line housing authorities, there is considerable zeal for section 23. Local authorities are naturally fond of their autonomy; the rent supplement program (to be administered by FHA, a rival subagency) was a threat to this traditional autonomy. Moreover, if the rent supplement had become the low-income housing program for the country, public housing in the conventional sense would have withered away, and the staffs of local authorities would have withered with it. The leasing program was a partial answer to the rent supplement-a counterproposal, in operation if not in theory, in defense of established local authorities. Moreover, local officials by and large believe in public housing. Attacks from right and left bewilder and anger them; budget and program cuts injure morale and make difficult the recruiting of good people. The leasing program is

139 Telephone Interview with William Newman, St. Paul Housing Authority, June 5, 1967; interview with Irwin Halpern, supra note 52.

140 See text accompanying notes 119-122 supra.

141 Burstein, supra note 92.

142 See 1965 Honse Hearings, pt. I, at 456-58. 
new, exciting, untarnished by scandal or failure and, most important, belongs to them.

Emphasis on local administration, however, has led to radical decentralization of the program. A great deal of unreviewed discretion is vested in local authorities and administrators. The selection and treatment of tenants, the speed and pace of the program-indeed, the decision whether to have a program at all-is firmly in the control of local authorities. This is not to suggest that such decentralization is inherently evil. However, it does mean that, in many respects, one cannot speak of the leasing program as a single entity, but rather only as many programs, loosely governed from Washington and the regional offices, and tightly identified with local interests and policies. Moreover, the likelihood is that the leasing program will continue to be decentralized, although it is possible for the program to be given greater direction from the center.

As in conventional public housing, financial control from above is stricter than control over management. The regional HAA staff in San Francisco, for example, has worked with great zeal and imagination to sell the program. It has done a magnificent job of inducing cities in its area to join. Other regional offices have also played a missionary role. But HAA, and its suboffices, can exert only so much pressure; the government prudently abstains from interference with operating programs so long as these programs remain within the broad limits of legality and overall policy.

Decentralization is also politically inescapable. Although the power of Washington over welfare programs generally has been increasing, most welfare programs involving any significant degree of administrative discretion are still firmly local. This is true whether they are in the form of state-federal partnership (such as AFDC), or are purely federal in form. The fact that it takes a purely federal form does not mean that a program is tightly centralized. The selective service program, for example, is completely federal and yet in practical operation has been run by independent satraps on the most local of local levels. The purely federal postal service, on the other hand, is strongly centralized. When a program does take the path of centralization, it may give up most of its discretionary features (for instance, consider the proposed nondiscretionary centralized revisions of the draft law). It is not administratively impossible to run a program from Washington; rather, the difficulties are political. They arise out of strong pressures from powerful local interests.

From the standpoint of local power-holders, the ideal federal program is an outright grant with no strings attached. This, however, is an unrealistic expectation. The next best program is one that is 
radically decentralized, with only fiscal or nominal controls, but with initiative left firmly in the hands of local leadership. This has been the experience of conventional public housing and, to an even greater degree, the urban renewal program. ${ }^{143}$

Public housing does not begin by adopting a specific concrete need as a goal and then devising action to reach that goal. If the underlying need is low-income housing for people with incomes under a certain level or suffering from certain social or other disabilities, a rational program would identify the potential beneficiaries and then appropriate enough money to meet the need-or at least as much of the need as is financially possible-where the need exists. But this approach is not possible politically; it might conceivably result in spending billions on New York, Chicago, Philadelphia and Cleveland, without a cent for Santa Barbara or White Plains. The political facts of life demand decentralization; they demand that every part of the country and indeed every state get its cut, if it wants it, and that the local unit define its own needs and purposes. So, in the public housing program, the result of decentralization is that money will flow where and in what amounts it is wanted or tolerated, which is not by any means the same as where or in what amounts it is needed.

These shortcomings of decentralization are bound to occur in the leasing program, since it must be approved locally before it can go into operation. Hence, leasing will not be, strictly speaking, one program, but rather will be the kind of protean "tool" that other welfare-housing programs have become. Cities differ tremendously in what they do with their leasing programs. Some cities are catering to the members of the submerged middle-class (this, for example, was the early situation in San Francisco). Others are stressing the elderly (as for example, St. Paul, Minnesota and Chicago). In Chicago, almost fifty per cent of the tenants are housed in homes in which they were already living, while the Pittsburgh Authority does not use this technique at

143 The renewal program-whatever the elaborate, glittering goals set out in its preambles and in speeches by proponents-is essentially a gift of federal gold, for urban programs which are devised locally, for local purposes and with local initiative. Despite the volumes of rules and regulations, urban renewal does not mean anything specific; it is here a coliseum, there a parking lot, still elsewhere a college campus, a hospital, luxury apartments or a stretch of lawn; it is a federal transfusion to help out an ailing downtown; or, conversely, money for suburban shopping centers causing the central city to decay still more; it is everything and nothing, depending upon who is the local prime mover and what the prime movement is about. See L. FRrEDMan, Government and Slum Housing: A Century of Frustratron ch. IV (1968). There is an enormous literature on urban renewal. The legislative history is given briefly in Foard \& Fefferman, Federal Urban Renezval Legislation, 25 LAW \& CoNTEMP. PROB. 635 (1960). This essay, and others dealing with various phases of urban renewal, have been collected in URBAN RENEWAL, THE RECORD AND THE CoNTROVIRSY (J. Wilson ed. 1966). Two studies, S. GreER, URBan ReNewal and AMERICAN Cities (1965) and C. Abrams, The CTry is THE Frontrer (1965), are particularly valuable. 
all and instead stresses vacant homes. ${ }^{144}$ Washington, D. C., has elected to use leasing as a weapon to rehabilitate houses. Other cities have used leasing as a way of bailing-out failing real estate ventures (we have mentioned Holyoke, Massachusetts and St. Paul, Minnesota as examples). Oklahoma City has used its program to solve the problem of finding relocation housing for persons driven from their homes by governmental action. In Omaha, the program houses large families who cannot be accommodated in conventional projects. And so it goes. The requirements of the law are few. The 10 per cent limitation, the 3 per cent vacancy rate, the options available to the landlord in selecting tenants, the length of the lease between the authority and the landlord-none of these are limitations that really bind; each city, with the help and encouragement of HUD, has been working out more or less its own destiny in the program.

Diversity, of course, is not an evil. The cities, after all, differ vastly from each other in demographic, social and economic characteristics. New York City cannot have the same scale and type of project as Witchita, Kansas, a city with no conventional public housing primarily single-family homes and a quite different population mix; diversity is a necessity. The question is only how much and in what directions.

\section{E. The Flight From Paternalism (and Some Backsliding)}

Conventional public housing is frequently criticized on the ground that it vests too much power in the government and too little in the tenants. No one has a right to public housing. Entry criteria are set exclusively by administrators, within very broad statutory limits. Once admitted, families have no security of tenure. ${ }^{145}$ The tenant will be required to abide by the rules and regulations laid down by the authority, and to conform to behavior patterns expected by the authority and its resident manager. In most public housing projects, the tenant will have no voice in the making or unmaking of these regulations. If he fails to pay his rent, or if he misbehaves, or if his income rises above the limits laid down for the project, he is liable to be summarily evicted. ${ }^{146}$ Even more important than the formal rules and

144 "This is our policy, to bring homes back on the market, that's what the program is-bring homes back on the market and shape them up." Telephone Interview with Thomas Gralewski, Leased Housing Section, Pittsburgh Housing Authority, Pittsburgh, Pennsylvania, June 6, 1967.

145 The typical public housing lease is written on a month-to-month basis; indeed, the Managennent Handbook recommends such a lease, since it permits "any necessary evictions to be accomplished with a minimum of delay and expense." Nat' Ass'n of Housing \& Redevelopment Officials, Public Housing is the Tenants, in 3 Changrng Concepts of the Tenant-Managenent Relationship A-60 (1967). See Friedman, Public Housing and the Poor: An Overview, 54 CALIF. L. REv. 642, 659-61 (1966). 146 In practice, some public housing managers are quite lenient with over-income tenants. There is a statutory escape clause, Housing Act of 1961, $\$ 205(\mathrm{~g})(3), 42$ U.S.C. $\$ 1410(\mathrm{~g})(3)(1964)$, but apparently it is little used. 
regulations which govern public housing is the general atmosphere within the project, which may range from genial permissiveness, through bumbling inefficiency, all the way to despotism. There are few formal controls over the way projects are governed, although recent litigation may stimulate additional safeguards. ${ }^{147}$ The style of management varies a great deal from project to project and from city to city; some housing authorities are much more paternalistic than others.

Pressure for change, however, has accelerated the trend away from authoritarianism in public housing in recent years. ${ }^{148}$ The whole climate of authority within public housing projects is shifting away from traditional paternalism. It is this shift that has made it possible for section 23 housing to exist. Section 23 housing presents fewer opportunities for extreme bureaucracy and paternalism. It is easier to manage tenants' lives if they are massed together in one project with clearly defined boundaries separating the project from the outside world. Section 23 tenants are scattered about the city, so that, even though the same rules and regulations ostensibly apply to leased housing tenants as apply to tenants in conventional public housing, it is more likely that as to the former these will be paper rules. Indeed, conservative rules within the leasing program may be largely a matter of inertia; it is much easier to use handy old forms than to draft wholly new ones. The authority will continue to be strict about rent payments, but it will not, in general, care about many other regulations so long as the owner does not complain. One wishes, however, that at least a few formal changes had been made. The Oakland lease still states that "this lease agreement may be cancelled by the AuTHORITY by giving 10 days advance notice in writing to Tenant." 149 Under the program, landlords get security of tenure, but the government does not trust

147 Some of these cases are described in 8 Welfare L. BuLx., May 1967, at 3-7; 7 WetFare L. Bull., Feb. 1967, at 7.

148 Meaningful tenant councils have been formed in a number of cities. In Richmond, California, for example, tenants at the Easter Hill project, with OEO help, have formed a strong organization, which plays an important and constructive role in making policy. Law suits have been brought against housing authorities to force them to modify their rules or to give to their tenants more procedural or substantive rights. See, e.g., Thorpe v. Housing Authority, 386 U.S. 670 (1967). Partly in response to these new pressures, HUD has demanded that local agencies formalize their eviction procedures and grant more procedural rights to their tenants. HUD, Terminations of Tenancy in Low-Rent Projects, Feb. 7, 1967, quoted in 8 WeLFARE I. BuLl., May 1967, at 4. Some authorities have adopted new rules and granted new powers to tenants and tenant organizations, either to forestall trouble or because they are aware for the first time that a problem exists.

149 Housing Authority of the City of Oakland, California, Resident Lease Agreement, Section 23 Housing, at $2, \pi 5$. The tenant can cancel "by giving 30 days' advance notice in writing to the AUTHORTYY." By paragraph 6, the Authority reserves the "right to modify, change, alter or amend the provisions of this lease upon 10 days' written notice to the TENANT." 
its own subtenants enough to formalize their relationship with any kind of security of tenure. ${ }^{150}$

Backsliding toward paternalism is also likely to be a danger in two other areas: the selection and screening process, and housekeeping inspections of tenants' homes. Since there have never been nearly enough public housing units to fill the needs of all potentially eligible tenants, distinctions have had to be made among low-income families who apply. These distinctions could be based on any one of three general standards: need; merit; and objectified standards (for example, a first-come first-served standard for applicants). In theory, need has always been the basic criterion. The federal statute requires each local public housing agency to "adopt and promulgate regulations establishing admission policies which shall give full consideration to its responsibility for the rehousing of displaced families," and to "urgency of housing need." 151 Many local authorities have their own tables of preferences and priorities, giving a special place to families displaced by urban renewal, families without housing and families living in substandard housing. These are, presumably, elements of a definition of need. Degree of poverty, ironically enough, is not one of the elements of this definition. Tenants must be poor to be eligible, and are poor of course; but it is not advantageous to an applicant to be very poor. Indeed, if he cannot pay his rent, he is not eligible at all. If it were not for AFDC, social security and other independent features of the welfare system, most of the tenants in the country's largest projects would be shut out of public housing by virtue of the same poverty which made them eligible to apply. This aspect of public housing law is not surprising or accidental. Public housing was originally intended for the lower working class and those subsisting on "honorable" pensions. It was, in other words, strongly suffused with considerations of merit.

Merit, in one guise or another, keeps creeping into the public housing program. The federal statute, for example, requires local authorities to give consideration, not only to the needy categories mentioned, but also to servicemen and veterans. ${ }^{152}$ Public housing management, throughout its history, has persistently searched for tenants drawn from the "worthy poor" or, as we have called them, the submerged middle class. It is a standard of merit, fully as much as considerations of need, which explains the great popularity of programs for housing

150 In San Francisco, one year leases have been granted to section 23 tenants. Williams, sipra note 66. But apparently the Local Authority there does so only because it believes that it is obligated by law to grant such terms. The belief, which is quite erroneous, may be due to a misreading of Housing and Urban Development Act of $1965, \S 23$ (d), 42 U.S.C. $\$ 1421 \mathrm{~b}$ (d) (Supp. I, 1965), which prescribes a one year minimum for leases between the local authority and an ozmer.

15142 U.S.C. $\$ 1410$ (g) (1964).

152 Id. 
the elderly; the elderly are the largest remaining pool of well-behaved, white, deserving applicants for public housing. ${ }^{153}$ And the housing law also shows a special solicitude for the handicapped poor ${ }^{154}$ for similar reasons.

It is clear that the leasing program in many cities reflects the same definite commitment to seek out and help primarily the deserving poor. Many of those who run the program are convinced that leasing will not succeed, unless the right kind of tenant can be placed in the right kind of apartment. Troublemakers and the morally disreputable are even less welcome than in conventional public housing. A St. Paul, Minnesota, official, worried about acceptance of low-income families, promises that there will be "no back-door integration," or placing of "low-income people in incompatible situations." 155 In San Jose, California, the informal policy is to reject prospective tenants for malicious damage to their prior home, recent criminal background or alcoholism. ${ }^{\mathbf{1 5 6}}$ It is understandable that leasing officials will wish to exclude some kinds of deviants-for example, those who have a propensity to destroy their landlord's property. But there are victimless deviants, such as unwed mothers, for whom a policy of exclusion is much harder to justify.

Leasing administrators also lay great stress on the "housekeeping" habits of their tenants, an emphasis already apparent in the demonstration projects preceding passage of section $23 .{ }^{157}$ Of course, mothers

153 For this reason, programs to help the elderly have a great deal of political appeal. Congress has granted extra subsidies to aid construction of housing for the elderly. See, e.g., 42 U.S.C. $\$ 1410$ (a) (additional public housing subsidy of up to $\$ 120$ "per annum for dwelling unit occupied by an elderly family"). Many cities which have shown little or no interest in conventional public housing have eagerly embraced public housing for the elderly. In the New York region, as of December 31,1965 , of 11,937 units under construction, 7,488 were for the elderly; in the Chicago region the count was 6,133 out of 9,003. These figures are drawn from PHA LowIncome Directory (Dec. 31, 1965). In some of the other regions the figures were not quite so striking, but everywhere the elderly poor were somewhat overrepresented in the construction figures. See text accompanying note 69 supra.

154 See 12 U.S.C. $\$ 1701$ (q) (1964).

155 Telephone Interview with William Newman, Leasing Section, St. Paul, Minnesota Housing Authority, June 5, 1967.

156 However, a sample of 100 rejections of applicants in San Jose broke down as follows :

$\begin{array}{lr}\text { Over-income } & 39 \\ \text { Non-residence } & 64 \\ \text { Excess net assets } & 4 \\ \text { Poor housekeeping } & 4 \\ \text { Inability to pay rent } & 1\end{array}$

These figures do not reflect summary rejections by telephone. If these were included, the factor of non-residence might be even more exaggerated. San Jose is a rapidly growing city, with irregular boundaries and numerous islands and peninsulas of unincorporated county land near the city. The residence requirement is two years. D. Commons, S. Dolberg, F. Katz \& A. Sherry, Report on the Housing Authority of San Jose, May, 1967 (unpublished seminar paper, Stanford University Law School). 157 In one, "evidence of good housekeeping potential was essential for families selected. Housekeeping ability was considered important because of the scattered location of the houses." Aronov \& Smith, supra note 84, at 483. 
with a dozen children are particularly apt to lack "good housekeeping potential." And the requirement is in a way discriminatory. Many middle-class housewives are poor housekeepers and, indeed, some are proud of it. Nonetheless, the notion that a place in the leasing program must be merited, and that good housekeeping is a sign of merit, will continue to be strong in many cities, judging by experience thus far.

The policing of tenants' homes and lives continues, in most cities, after tenants have been placed in leased housing. In San Jose, California, tenants' apartments are visited every other month, mainly to see that the tenant is a good housekeeper. A work sheet, prepared for use by the tenant-relations department, gives these instructions to the inspectors:

Make a room-by-room inspection . . . call their attention to accumulation of finger marks on walls, dirty floors, garbage in kitchen, garbage in yard, unmade beds, children playing outside barefoot or inadequately clothed for cold weather. A trained observer can tell the difference between an unmade bed and one that is seldom made.

Point out to them that as long as there is a marked improvement upon the next visitation, no action other than documenting each visit will be taken. ${ }^{158}$

In Washington, tenants are visited every month or six weeks; in Chicago, where most of the tenants are elderly, "we try to hit them at least once a year." Many authorities would like to inspect more often, but since the housing is scattered, inspections are quite wasteful of time and manpower. ${ }^{159}$

Not all cities screen tenants carefully or police them rigorously after placement. In some cities, applicants are gathered from the general pool of public housing applicants; in still others, screening is minimal, either because the program caters primarily to the elderly (who are in general a troublefree group) or because, as in Oklahoma City, the overriding purpose of the program (relocation) makes screening unnecessary or undesirable. Boston makes no regular housekeeping inspections, since it does not "want tenants to be wards of the state, with people barging in at all hours." 160 Landlords, of course, can complain if their tenants are derelict in their behavior, but so far few have. The programs studied are too new for any major tenant reaction to screening and policing to have developed. Moreover, the

158 Quoted in D. Commons, supra note 156.

159 "In Chicago, the inspections are a slower thing than in a high-rise; you have to go miles between buildings. And elderly people like company. They'll keep you there two hours talking if you let them, especially in the winter, when they don't go outside." Telephone Interview with Gene Chmura, supra note 52.

160 Telephone Interview with Frank Powers, supra note 13. 
scattered nature of leased housing limits the ability of tenants to join together and make effective protest. Housekeeping inspections have not evoked much complaint. A few problems arise here and there, chiefly because of rent defaults, physical damage to property and drunkenness. But major difficulties are rare.

The policy of supervising tenant housekeeping and morals as a basis for eligibility and continued occupancy can be criticized on a number of grounds. One is quite simply that such supervision, however well intended, is imposed upon tenants without their consent and is unfair and discriminatory. Another objection is that the staff and financial resources put into policing the lives of the poor would be better employed in raising their real standard of living. The costs, in other words, are not warranted by the benefits. If there are benefits from close supervision, they are of two kinds: first, that close control deters tenants from committing socially disapproved acts; second, that supervision brings about an improvement in the way of life of the poor. The first benefit is questionable; whether surveillance of the kind within the capabilities of housing authority employees will deter anyone from drunkenness, drug addiction, childbearing out of wedlock or even poor housekeeping remains undemonstrated. The second benefit is just as questionable, for "improvement" is extremely difficult to measure. Close supervision means that the poor are offered the concrete benefit of better housing at the price of conforming their behavior to the behavior of the middle class. No doubt millions of the poor would gratefully adopt middle class behavior and values if they could afford them. In a democratic society, however, the line between voluntary and coerced behavior is an essential one. A democracy is sometimes willing to coerce behavior; thus, it vaccinates people against their will if necessary. But a clear showing of social gain and that the coercion will actually affect behavior in the desired manner are necessary to make coercion ethically acceptable. Can these two conditions be met by the exclusion policies of housing authorities?

Policies of close supervision strongly bias the program toward the deserving poor and away from a standard based purely on need. The policy of seeking out the deserving poor, however, has to be understood in context. Our society refuses to allocate substantial resources toward housing the poor. Hence, the authorities must make cruel choices among those formally eligible.

The authorities have chosen to use the limited resources available to help those who, in their opinion, most readily respond to helpthose whose needs are purely for better housing, rather than for a variety of social services. In their view, it would be a waste of re- 
sources to house those who would be no better off in good housing than they were before. A drug addict, to take an extreme case, will remain a problem to himself and society whether or not he has standard plumbing and the correct cubic footage of space.

One can accept this position in principle and still quarrel with the way in which housing authorities have defined the type of tenant who can benefit from the program and who should share in its subsidy. An authority cannot be blamed for attempting to make its section 23 dollars do the most work with the least strain; but it is perhaps too easy a solution to confine one's program to such popular and harmless tenants as the elderly.

There are unfortunate families in great poverty who have at least a strong ethical claim on the program and who would profit from the chance of a decent home in a decent area, but who present more risk than the elderly of falling short of perfection in tenant behavior. The current system is, therefore, far from ideal: it discriminates against those who need it most; it is flawed by remnants of discretionary bureaucratic power beyond the legitimate needs of the program. On the positive side, however, it reaches slightly deeper down into the ranks of the poor, and does slightly more for those it helps, than do many other government social programs. At this stage of the program, and in the political context of the 1960's, housing officials seem convinced that the program must run smoothly and without scandal in order to assure itself of permanence and a greater claim on funds. If we accept these premises, we might reluctantly agree that, however odious is the notion of earning the right to a decent home, it is better to allow privileges to some rather than to none. But, as we have pointed out, this means that the program is far more limited in its current aspirations than some have claimed for it. It is capable, at present, of making only marginal advances toward solving housing problems. In particular, the leasing program will not materially aid the most desperately poor, since it looks in most cases for those who can be housed without greatly interfering with existing racial and economic patterns and without risking the scandal-free record of the program.

Yet it is certainly far too early to be pessimistic. The leasing program has helped the public housing movement revive from the lethargy of a decade or more. The movement is travelling, on the whole, in a salutary direction. If it is not diverted from its course by the babel of local voices, and if it does not backslide into excessive paternalism, the program will mark a genuine advance over conventional public housing and will make possible a real betterment of life for many of the poor. 